\title{
"The potential of conflicts of interest arising in the activities of credit rating agencies in Ukraine"
}

\begin{tabular}{|c|c|}
\hline AUTHORS & $\begin{array}{l}\text { Mykhailo Rebryk } \\
\text { Yuliia Rebryk } \\
\text { Sergii Sokol } \\
\text { Yevhenii Kozmenko (D https://orcid.org/0000-0003-2721-2997 }\end{array}$ \\
\hline ARTICLE INFO & $\begin{array}{l}\text { Mykhailo Rebryk, Yuliia Rebryk, Sergii Sokol and Yevhenii Kozmenko (2017). } \\
\text { The potential of conflicts of interest arising in the activities of credit rating } \\
\text { agencies in Ukraine . Problems and Perspectives in Management, 15(2-1), 222- } \\
\text { 233. doi:10.21511/ppm.15(2-1).2017.06 }\end{array}$ \\
\hline DOI & http://dx.doi.org/10.21511/ppm.15(2-1).2017.06 \\
\hline RELEASED ON & Tuesday, 18 July 2017 \\
\hline RECEIVED ON & Monday, 03 April 2017 \\
\hline ACCEPTED ON & Friday, 26 May 2017 \\
\hline LICENSE & $\begin{array}{l}(c) \text { EY-NG } \\
\text { This work is licensed under a Creative Commons Attribution-NonCommercial } 4.0 \\
\text { International License }\end{array}$ \\
\hline JOURNAL & "Problems and Perspectives in Management" \\
\hline ISSN PRINT & $1727-7051$ \\
\hline ISSN ONLINE & $1810-5467$ \\
\hline PUBLISHER & LLC "Consulting Publishing Company "Business Perspectives" \\
\hline FOUNDER & LLC "Consulting Publishing Company "Business Perspectives" \\
\hline
\end{tabular}

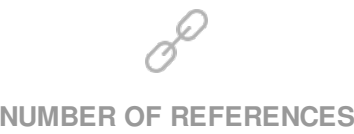

26
NUMBER OF FIGURES

1
NUMBER OF TABLES

5

(C) The author(s) 2023. This publication is an open access article. 


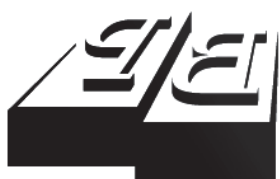

BUSINESS PERSPECTIVES

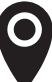

LLC “CPC "Business Perspectives" Hryhorii Skovoroda lane, 10, Sumy, 40022, Ukraine

www.businessperspectives.org

Received on: $3^{\text {th }}$ of April, 2017 Accepted on: $26^{\text {th }}$ of May, 2017

(C) Mykhailo Rebryk, Yuliia Rebryk, Sergii Sokol, Yevhenii Kozmenko, 2017

Mykhailo Rebryk, Ph.D. in Economics, Associate professor of the Chair of Finance and Credit, Cherkasy Institute of the SHEI "University of Banking”, Ukraine.

Yuliia Rebryk, Ph.D. in Economics, Associate professor of the Chair of Finance and Credit, Cherkasy Institute of the SHEI "University of Banking", Ukraine.

Sergii Sokol, Ph.D. in Economics, Associate Professor, Department of Finance and Credit, Kharkiv National University of Construction and Architecture, Ukraine.

Yevhenii Kozmenko, Student, Sumy State University, Ukraine.

\section{(ㄷ)(1) $(9$}

This is an Open Access article, distributed under the terms of the Creative Commons Attribution-NonCommercial 4.0 International license, which permits re-use, distribution, and reproduction, provided the materials aren't used for commercial purposes and the original work is properly cited.
Mykhailo Rebryk (Ukraine), Yuliia Rebryk (Ukraine), Sergii Sokol (Ukraine), Yevhenii Kozmenko (Ukraine)

\section{THE POTENTIAL OF CONFLICTS OF INTEREST ARISING IN THE ACTIVITIES OF CREDIT RATING AGENCIES IN UKRAINE}

\begin{abstract}
This paper presents a comprehensive system of 38 indicators, which allows identification of possible endogenous sources and evaluation of the potential of conflicts of interest arising both at the corporate (in models of ownership, business and financial activities, corporate governance and organizational structures) and operational (analyst) levels of credit rating agencies (CRAs).

Testing of proposed system of indicators was carried out based on the content analysis of the public information on the activities of five authorized credit rating agencies of Ukraine.

It is determined that at the beginning of 2017 the most sensitive to the risk of conflicts of interest were "Standard Rating" (74\% of threat signals of the total number of indicators), "Expert Rating" (57\%) and "Rurik" (37\%). The highest potential of conflicts' of interest escalation was identified in the models of financial activities $(80 \%$ of threat signals of the total number of indicators of that group) and models of ownership of Ukrainian CRAs (63\%).

The estimations of the risk level are proposed to be regarded mainly as signals of the potentially high sensitivity of the particular CRA to the risk of conflicts' of interest escalation.

Such signals, in particular, can be used by the regulators for carrying out remote monitoring activities of CRAs, for adopting supervisory and regulatory decisions. In turn, managers and owners of rating agencies can conduct a more detailed analysis of the detected potential sources of conflict of interest with the aim of identification, localization, and elimination of shortcomings in the system of conflict of interest management.
\end{abstract}

Keywords

credit rating agencies, CRA, risk of conflicts of interest, system of indicators, CRA independence, transparency

JEL Classification G24, G32, G38, M14

\section{INTRODUCTION}

As international experience shows conflicts of interest in the activities of credit rating agencies may lead to a significant devaluation of the credit ratings' quality due to rating shopping, manipulations and problems with disclosure. As a result, substantial adverse externalities could be generated. Among them - the possibility of destabilization and contagion of financial markets, distortions in the pricing of securities, deterioration in the financial conditions and bankruptcy of some companies and even states, etc.

On the other hand, the devaluation of the quality of ratings leads to erosion of reputational capital of CRAs, reducing investors' confidence in them as in information intermediaries and as a result - to a partial loss of clients and therefore - of income. 
Hence, the issue of the development of an effective mechanism for identifying potential sources of conflicts of interest for the purpose of their further localization and elimination does not lose its relevance for regulators of rating services markets as well as for managers and owners of CRAs. The latter must be ultimately responsible and interested in ensuring the effective management of conflicts of interest.

The article aims, therefore, to design and empirically test on the example of Ukrainian CRAs a comprehensive system of indicators, which allows identification of possible endogenous sources and evaluation of the potential of conflicts of interest arising both at the corporate (agency) and operational (analyst) levels of functioning of CRAs.

The remainder of the paper is organized as follows. In Section 1 we discuss the main endogenous sources of conflicts of interest faced by CRAs, described in the academic literature and in the regulations. In Section 2 the methodology of research and model of calculation of proposed index of the risk of conflicts' of interest escalation is described. In Section 3 we empirically analyze indicators concerning the potential of conflicts of interest both at the corporate and operational levels of CRAs' functioning. Section 4 provides concluding remarks.

\section{LITERATURE REVIEW}

The conflicts of interest problem is a part of a broader field of research dedicated to finding causes of failures in CRAs' activities and rating inflation. Such scholars as P. Bergevin, J. Katz, J. C. Coffee, Jr., C. C. Opp, M. Opp and M. Harris, F. Partnoy, while focusing mainly on studies of exogenous sources of conflicts of interest, noted that one of the main reasons for inflated ratings is the business model (in particular the "issuer-pays" model) of the major CRAs.

J. C. Coffee, Jr. (2011) even identifies two basic camps of the reformers of CRAs' activities: (1) those who see the "issuer-pays" model of the major CRAs as the fundamental cause of inflated ratings, and (2) those who blame the licensing power given to CRAs by regulatory rules.

However, he and some other researchers argue that "subscriber-pays" model, where ratings are paid for by investors through subscription fees, can also give rise to conflicts of interest, as investors, as well as issuers, also have serious conflicts of interest. In particular, some institutions might pressure a CRA to assign an investment-grade rating on a particular security because the value of the security holdings or the status of regulatory compliance of such subscribers depends on the ratings of the securities (Bai, 2010). On the other hand, Partnoy (2009) notes that large investor could try to influence CRA to provide lower initial ratings, which tend to provide higher yields.
In the Report on the activities of CRAs (IOSCO, 2003) experts of the International Organization of Securities Commissions (IOSCO) determine that, except for issuer fees ("issuer-pays" model), the main sources of conflicts of interest can be hidden in the access to non-public information (insider trading), providing ancillary advisory services, having financial interests in rated issuers, and issuing of unsolicited ratings.

Later in the Code of Conduct Fundamentals for Credit Rating Agencies (IOSCO CRA Code) experts of the IOSCO summarize that conflicts of interest arise due to the CRA's ownership structure, business or financial activities, or the financial interests of the CRA's employees (IOSCO, 2015).

Thus, as it is fairly observed by L. Bai, conflicts of interest arise both at the individual credit analyst level and the rating agency level (Bai, 2010). According to her view, agency-level conflicts typically arise in the following settings regarding the activities of CRAs: (1) affiliated underwriter or issuer; (2) ancillary services to rated entities; (3) large subscriber influence, and (4) "issuer-pays" business model.

L. Bai argues, in particular, that the provision of ancillary services by CRAs is also a source of conflicts of interest, because rating decisions of agencies may be influenced by an issuer's decision whether or not to purchase additional services of- 
fered by them. Issuers may be pressured into subscribing to such services simply out of fear that their failure to do so could adversely impact their credit rating (or, conversely, with the expectation that purchasing these services could help their credit rating) (IOSCO, 2003).

Crumley (2012), in addition, notes that issuers could receive preliminary ratings in the form of consulting services from several CRAs simultaneously that could give them an opportunity to choose among those agencies the one which offers the highest estimation. Such rating shopping significantly distorts the estimates of the real level of credit risk and complicates making objective investment decisions.

She also adds that conflicts of interest could also arise due to the issuance of unsolicited credit ratings, which are published by credit rating agencies without the request of the issuer or its agent. Some academic literature (Bai, 2010; Partnoy, 1999; Fulghieri, Strobl \& Xia, 2011) describes several known examples from the international practice when CRAs forced clients to order rating coverage, to buy ancillary services or to pay higher fees by using the fact or even only a threat of assignment of hostile unsolicited ratings.

Fulghieri, Strobl, and Xia (2011) by using the dynamic rational expectations model of the credit rating process also show that issuing unfavorable unsolicited ratings increases the CRA's reputation by demonstrating to investors (and supervisory authorities) that it could resist the temptation to issue inflated ratings.

We agree with the conclusions of L. Bai that conflicts of interest at the analyst level deal with inappropriate contact between the raters and the rated, or an analyst's personal interest in improved performance of the issue. Thus, she identifies the following potential areas where conflicts of interest may arise: (1) ownership of securities of rated entities; (2) employment position or directorship at a rated entity; (3) business relation beyond ordinary course of business or special purpose relationship; (4) receipt of gifts from rated entities; and (5) the determination of analysts' compensations based on rating fees (Bai, 2010).
A wide range of endogenous sources of conflicts of interest regarding the activities of CRAs, except IOSCO CRA Code (IOSCO, 2015) and IOSCO reports on activities of CRAs (IOSCO, 2003; IOSCO, 2012), is also implicitly contained in the provisions of legislation in the sphere of regulation of CRAs' activities (in particular, EU Regulations № 1060/2009 (The European Parliament and the Council, 2009), No. 449/2012 (The European Parliament and the Council, 2012)), and Regulatory technical standards of the European Securities and Markets Authority (ESMA, 2011).

In particular, ESMA (2011) requires CRAs to provide information in order to assess any conflicts of interest arising from (1) the activities and business interests of their owners, (2) the carrying out of ancillary services, (3) the outsourcing of rating activities, (4) the interaction with related third parties; (4) the pitfalls in their corporate governance, (5) organizational structures, and (6) their policies and procedures with respect to the identification, management and disclosure of conflicts of interest and (7) the rules on rating analysts and other persons directly involved in credit rating activities.

Highly appreciating the solidity of the developments of foreign scholars and practitioners, we should note, however, that their studies are primarily focused on the problem of conflicts of interest in the activities of international CRAs. Therefore, they do not take into account the specifics of the sphere of credit ratings' determination and updating in Ukraine.

In turn, Ukrainian researchers and practitioners (in particular, Babenko \& Chornyj, 2012; Pererva, 2012; Kozmenko \& Plastun, 2012; and others) only fragmentary cover certain aspects of conflicts of interest arising in the functioning of Ukrainian CRAs.

Thus, our paper contributes to the literature on the conflicts of interest problem by designing and empirically testing on the activities of five authorized Ukrainian CRAs the system of indicators, which allows quantifying the CRA's sensitivity potential to risk of conflicts of interest. 


\section{METHODOLOGY}

According to the results of summarizing of theoretical achievements of Ukrainian and foreign researchers and practitioners, it could be argued that conflicts of interest at the corporate level are usually generated due to the existence of significant shortcomings in the models of ownership, business and financial activities, corporate governance and organizational structures of CRAs. In turn, at the operational (analyst) level the main source of conflicts of interest is the violation of the principle of the independence of analysts and other employees of CRAs.

To achieve the goal of the paper we designed the system of 38 key indicators (which will be described in detail in Section 3) that may signal about the threat of conflicts' of interest escalation hidden in the outlined sources both at the corporate and operational levels of the CRAs' activities.

Testing of proposed system of indicators was carried out based on the research of the activities of five authorized Ukrainian CRAs in Ukraine: IBI-Rating, Rurik, Expert-Rating, Credit-Rating and Standard-Rating. The study was conducted in January 2017 based on the content analysis of the information published on the official websites of authorized Ukrainian rating agencies as well as publicly available information database of the National Securities and Stock Market Commission (NSSMC, 2017) of Ukraine.

The index of the risk of conflicts' of interest escalation was calculated as the ratio of the total number of detected signals about the threat of conflicts of interest in the activities of certain CRA to the total number (38) of proposed indicators.

\section{RESULTS}

\subsection{The potential of conflicts of interest in models of ownership}

According to the decision of the NSSMC (2012), the annual financial information, which authorized CRAs are obliged to publish on their webpages and disclose in publicly available information database of the NSSMC, should include, in particular, (1) basic data about the CRA indicating the information on its affiliates and their affiliation with participants of financial services markets as well as the determination of their credit ratings; (2) the information on the ownership of securities.

However, it should be noted that none of the authorized CRAs in Ukraine discloses on its official website any data about its ownership structure. The information is limited only to declarative statements about the independence of CRAs, the absence of affiliation with participants of financial services markets and rated entities (as required by the decision of the NSSMC, 2015). Moreover, the mandatory information on ownership of securities of rating agency Rurik is not published even in publicly available information database of the NSSMC, which is a direct violation of the current Ukrainian legislation.

The ownership structures of Standard-Rating and Expert-Rating remain extremely non-transparent. Thus, Standard-Rating is controlled at $90 \%$ by international private rating company "Standardrating" registered in London (NSSMC, 2017). The latter company is headed by A. Nikitin (the Director of the Ukrainian agency "StandardRating") and its sole shareholder is Jason Hughes, who was the director of the GPRC "Standardrating" until 2013 (BizDb, 2017). Jason Hughes also currently heads (apparently - nominally) more than 150 companies (Endole, 2017), which significantly complicates the identification of the real owners and affiliates of Standard-Rating.

The owner of $50 \%$ of the equity of Expert Rating's, de jure, is Thorium Limited, LLC from Cyprus well-known offshore jurisdiction with possibilities of nominal services and high level of owners' confidentiality (NSSMC, 2017). Therefore, de facto, it is hard to determine the final beneficiaries and affiliates of Expert-Rating as well.

In this context there was an interesting precedent of withdrawal of Credit-Rating's status of authorized rating agency. It was based on the decision of NSSMC No. 246 of 15.03.2011 after the allegations about agency's opaque ownership structure and linkages with financial market participants. 
Table 1. The warning signals concerning the potential of conflicts of interest in models of ownership of CRAs in Ukraine

\begin{tabular}{|c|c|c|c|c|c|c|}
\hline \multirow[b]{2}{*}{ No. } & \multirow[b]{2}{*}{ Indicators } & \multicolumn{5}{|c|}{ Credit rating agencies } \\
\hline & & IBI-Rating & Rurik & $\begin{array}{l}\text { Expert- } \\
\text { Rating }\end{array}$ & $\begin{array}{l}\text { Credit- } \\
\text { Rating }\end{array}$ & $\begin{array}{l}\text { Standard- } \\
\text { Rating }\end{array}$ \\
\hline & The opaque ownership structure & - & + & + & - & + \\
\hline & $\begin{array}{l}\text { The presence of persons associated with participants of } \\
\text { financial services markets among CRA's affiliates }\end{array}$ & - & $?$ & $?$ & - & $?$ \\
\hline & Rating of affiliates & - & $?$ & $?$ & $+/-$ & $?$ \\
\hline \multicolumn{2}{|r|}{$\begin{array}{l}\text { The total number of detected signals about the threat of } \\
\text { conflicts' of interest escalation }\end{array}$} & 0 & 3 & 3 & 0.5 & 3 \\
\hline
\end{tabular}

Note: Legend (here and below): + - confirmation of the threat of conflicts of interest; - no threat of conflicts of interest detected; $+/$ - partial confirmation of the threat of conflicts of interest; ? - absence of any information regarding the particular indicator; * - potentially declarative information obtained from the CRAs' corporate codes of conduct or/and the Memorandum (IBI-Rating, Expert-Rating, and Rurik, 2010).

Thus, the information on the composition and activities of the real owners of Ukrainian CRAs currently remains fairly closed (Table 1). The vast majority of CRAs is associated with prominent businessmen or politicians. However, there is no official confirmation of these facts (Pererva, 2012). It significantly complicates the assessment of the potential conflicts' of interest escalation due to the influence of affiliation with rated entities and persons associated with financial services markets participants on the independence of CRAs.

In our opinion, the opacity of the ownership and affiliation structures of CRAs is not only inappro- priate given the nature of their functioning as information intermediaries, but also creates significant threats due to the conflicts of interest.

\subsection{The potential of conflicts of interest in models of business activities}

The potential sources of conflicts of interest are also presented in the models of business activities of Ukrainian CRAs (Table 2). They are mainly caused by the provision of ancillary services and issuance of unsolicited credit ratings.

Table 2. The warning signals concerning the potential of conflicts of interest in models of business activities of CRAs in Ukraine

\begin{tabular}{|c|c|c|c|c|c|c|}
\hline \multirow{2}{*}{ No. } & \multirow{2}{*}{ Indicators } & \multicolumn{5}{|c|}{ Credit rating agencies } \\
\hline & & IBI-Rating & Rurik & $\begin{array}{l}\text { Expert- } \\
\text { Rating }\end{array}$ & $\begin{array}{l}\text { Credit- } \\
\text { Rating }\end{array}$ & $\begin{array}{l}\text { Standard- } \\
\text { Rating }\end{array}$ \\
\hline & Providing ancillary services & + & + & + & + & + \\
\hline & Providing consultancy or advisory services & + & + & - & + & - \\
\hline & $\begin{array}{l}\text { The absence of operational separation of the credit } \\
\text { rating business from any other businesses of CRA }\end{array}$ & $-*$ & $-*$ & $-*$ & $-*$ & $?$ \\
\hline & $\begin{array}{l}\text { The absence of legal separation of the credit rating } \\
\text { business from any other businesses of CRA }\end{array}$ & $-*$ & -* & + & -* $^{*}$ & $?$ \\
\hline & $\begin{array}{l}\text { A significant share of income }(>10 \%) \text { from the } \\
\text { provision of ancillary services }\end{array}$ & - & - & - & - & - \\
\hline & The issuance of unsolicited credit ratings & - & - & + & + & + \\
\hline & $\begin{array}{l}\text { The opacity of the goal, methodology and data sources } \\
\text { for the unsolicited ratings }\end{array}$ & - & - & - & - & - \\
\hline \multicolumn{2}{|r|}{$\begin{array}{l}\text { The total number of detected signals about the threat of } \\
\text { conflicts' of interest escalation }\end{array}$} & 2 & 2 & 3 & 3 & 4 \\
\hline
\end{tabular}


Ukrainian CRAs provide a wide range of ancillary services in addition to rating services. Among them are information services (analysis of counterparties, potential borrowers, debtors, etc.); consultancy services (on improvement and optimization of risk management system, on strategic and financial management with the aim of establishing business processes, on development of disclosure policies for banking institutions etc.); conducting sectorial researches (analysis of sectorial risks, the provision of passport of the industry, sector, segment of the economy, etc.); conducting round tables, seminars, trainings, etc.

To avoid conflicts of interest, the IOSCO CRA Code (IOSCO, 2015) recommends ensuring separation operationally and legally of the credit rating business and credit rating analysts from any other businesses including consulting businesses. It should be noted that such a principle is declared in the codes of conduct of the majority of Ukrainian CRAs, however, the question of its practical implementation remains open.

According to the results of 2014, a significant share of revenues from ancillary services was observed in the income structure of Rurik (21\%), ExpertRating (11\%), and Credit-Rating (10\%). It could serve as an indicator of rating shopping. However, in 2016 the share of CRAs' revenues from ancillary services did not exceed 3\%.

The analysis of methodologies of providing a wide spectrum of rating services by authorized CRAs indicates the signs of "unsolicitedness" of certain types of estimates: they are published without the order of the issuers and their agents. It concerns primarily the rating studies for the media, which are offered by Expert-Rating and Standard Rating, as well as the sovereign credit ratings of CIS countries, offered by Credit-Rating. In addition, the Standard-Rating has been practicing regular publication of the ratings of banks' deposits reliability, based on public information.

\subsection{The potential of conflicts of interest in models of financial activities}

As mentioned before, business models of payments for services of CRAs may also serve as one of the key catalysts of the problem of conflicts of interest. It is therefore important for CRAs to disclose the information about who pays for their rating services (issuers, underwriters, obligors or investors), whether there are cases of payments for ancillary services in addition to credit rating services, whether there are cases of receiving payments in the amount exceeding the average fees for similar services or whether there are clients whose contribution constituting a significant share of CRA's total income (e.g. more than $10 \%)$.

It should be noted that IBI-Rating, Rurik, and Credit-Rating, unlike Expert-Rating and StandardRating, declare in their corporate codes of conduct the obligations to disclose (1) the general nature of the tariff policy; (2) the ratio of other payments from rated entities (such as consultancy fees) to the payments for rating services.

Table 3. The warning signals concerning the potential of conflicts of interest in models of financial activities of CRAs in Ukraine

\begin{tabular}{|c|c|c|c|c|c|c|}
\hline \multirow[b]{2}{*}{ No. } & \multirow[b]{2}{*}{ Indicators } & \multicolumn{5}{|c|}{ Credit rating agencies } \\
\hline & & IBI-Rating & Rurik & $\begin{array}{c}\text { Expert- } \\
\text { Rating }\end{array}$ & $\begin{array}{c}\text { Credit- } \\
\text { Rating }\end{array}$ & $\begin{array}{l}\text { Standard- } \\
\text { Rating }\end{array}$ \\
\hline & The issuer-pays business model & $?$ & $?$ & $?$ & $?$ & $?$ \\
\hline & Large subscriber influence & $?$ & $?$ & $?$ & $?$ & $?$ \\
\hline & $\begin{array}{l}\text { The presence of clients whose contribution to the } \\
\text { annual income of CRA exceeds } 5 \%\end{array}$ & $?$ & $?$ & $?$ & $?$ & $?$ \\
\hline & The opacity of tariff policy & + & + & + & + & + \\
\hline & The opacity of financial statements & - & - & - & - & - \\
\hline \multicolumn{2}{|c|}{$\begin{array}{l}\text { The total number of detected signals about the threat of } \\
\text { conflicts' of interest escalation }\end{array}$} & 4 & 4 & 4 & 4 & 4 \\
\hline
\end{tabular}


Rurik additionally pledged to disclose the fact of receiving more than $10 \%$ of its annual income from one borrower, organization, user or client.

However, the information regarding the models of payment for services of Ukrainian CRAs, their tariff policy, fees for specific operations is not publically disclosed. That complicates the analysis of fees' impact on the determination of ratings with the aim to identify potential sources of conflicts of interest (Table 3). In public information database of the NSSMC, the annual financial statements of agencies are only available (presented by bal- ance sheets and income statements for 2014-2016). We managed to find only one publicly available example of charging for the rating services. The Department of the strategic city development of the Ternopil city Council ordered in 2016 from IBI Rating the rating coverage for 70 thousand $\mathrm{UAH}$. The rating coverage included (1) maintenance of the credit rating of the Ternopil city; (2) maintenance of the rating of investment attractiveness of the Ternopil city; (3) preparation of investment passport of the Ternopil city in Ukrainian and English languages (the number of printed copies - 30 pieces) (Prozorro.gov.ua, 2016).

Table 4. The warning signals concerning the potential of conflicts of interest in models of corporate governance and organizational structures of CRAs in Ukraine

\begin{tabular}{|c|c|c|c|c|c|c|}
\hline \multirow[b]{2}{*}{ No. } & \multirow[b]{2}{*}{ Indicators } & \multicolumn{5}{|c|}{ Credit rating agencies } \\
\hline & & IBI-Rating & Rurik & $\begin{array}{l}\text { Expert- } \\
\text { Rating }\end{array}$ & $\begin{array}{l}\text { Credit- } \\
\text { Rating }\end{array}$ & $\begin{array}{l}\text { Standard- } \\
\text { Rating }\end{array}$ \\
\hline & No obligation of compliance with the IOSCO CRA Code & - & - & - & - & $+/-$ \\
\hline & The absence of the corporate code of conduct & - & - & - & - & $?$ \\
\hline & $\begin{array}{l}\text { The opacity of the governance structure and the } \\
\text { organizational structure }\end{array}$ & $+/-$ & + & $+/-$ & + & $+/-$ \\
\hline & $\begin{array}{l}\text { The absence of independent members in the } \\
\text { administrative or supervisory board }\end{array}$ & + & + & + & + & $?$ \\
\hline & $\begin{array}{l}\text { The absence of independent auditors of the quality of } \\
\text { credit ratings }\end{array}$ & + & + & + & + & $?$ \\
\hline & $\begin{array}{l}\text { The absence of independent person responsible for the } \\
\text { identification, management and disclosure of conflicts } \\
\text { of interest }\end{array}$ & + & + & + & -* $^{*}$ & $?$ \\
\hline & $\begin{array}{l}\text { The absence of independent compliance function } \\
\text { department }\end{array}$ & -* $^{*}$ & -* $^{*}$ & + & -* $^{*}$ & $?$ \\
\hline & $\begin{array}{l}\text { The absence of policies and procedures to identify, } \\
\text { manage and disclose any conflicts of interest }\end{array}$ & -* $^{*}$ & $-^{*}$ & + & -* $^{*}$ & $?$ \\
\hline & $\begin{array}{l}\text { The lack of reporting and communication channels for } \\
\text { CRA's staff to eliminate or effectively manage actual and } \\
\text { potential conflicts of interest }\end{array}$ & $-^{*}$ & -* $^{*}$ & + & -* $^{*}$ & $?$ \\
\hline & $\begin{array}{l}\text { The violation of the principle of collective decision- } \\
\text { making on the determination of credit ratings }\end{array}$ & -* $^{*}$ & $-^{*}$ & -* $^{*}$ & -* $^{*}$ & $?$ \\
\hline & $\begin{array}{l}\text { The opacity of the duties and powers of the responsible } \\
\text { persons involved in the rating process }\end{array}$ & + & -* $^{*}$ & - & -* $^{*}$ & $?$ \\
\hline & $\begin{array}{l}\text { Poor internal records about important stages of the } \\
\text { rating process }\end{array}$ & + & -* $^{*}$ & + & $-*$ & $?$ \\
\hline & Disclosed cases of conflicts of interest & - & - & - & + & - \\
\hline & $\begin{array}{l}\text { The opacity of procedures and methodology of } \\
\text { assigning, updating, suspending, and withdrawing of } \\
\text { credit ratings }\end{array}$ & - & - & - & - & - \\
\hline & The opacity of the ratings history & - & - & - & - & - \\
\hline & Non-disclosure of rating reports & - & - & - & - & - \\
\hline & Non-disclosure of ratings accuracy statistics & - & - & - & - & - \\
\hline The t & $\begin{array}{l}\text { tal number of detected signals about the threat of } \\
\text { cts' of interest escalation }\end{array}$ & 5.5 & 4 & 7.5 & 4 & 11 \\
\hline
\end{tabular}




\subsection{The potential of conflicts of interest in models of corporate governance and organizational structures}

Information restrictions do not also allow to assess efficiently whether the corporate governance models and organizational structures of Ukrainian CRAs ensure the agencies' independence and the avoidance of conflicts of interest or not.

As could be seen from Table 4, on the official websites of the agencies there are actually no data according to the structures, functions and independence of the governing bodies of CRAs as well as the presence of independent members in their administrative or supervisory boards, independent auditors of the quality of credit ratings, on the composition, qualifications, duties and powers of the responsible persons involved in the rating process, the persons who check the quality of ratings, and persons responsible for the identification, management and disclosure of conflicts of interest.

To avoid conflicts of interest, all authorized CRAs also declare compliance with the principle of collective decision-making on the determination of credit ratings through the creation of rating committees.
However, we have identified numerous instances of violation by agencies of the commitments declared in their corporate codes of conduct. In particular, the non-compliance with obligations of disclosure of tariff policy, as it was mentioned previously. Another example - is the obligation to disclose the composition of the administrative or supervisory board and analytical department to ensure transparency of rating processes, declared by IBI Rating, Rurik, and Expert Rating in the Memorandum (IBI-Rating, Expert-Rating and Rurik, 2010). In fact, this commitment is implemented only partially: on the official website of Rurik there is no information on this issue; on the website of Expert-Rating it is possible to find the data regarding the Director and the chief financial analyst; IBI-Rating discloses only surnames, names, phone numbers, and e-mails of the Director and heads of departments.

It is positive that all authorized CRAs publish lists of ratings and rating histories backed up by the rating reports on their official websites. CRAs also disclose procedures and methodology of assigning, updating, suspending and withdrawing of credit ratings. In addition, to meet the requirements of NSSMC, agencies share reports with statistics of defaults by rating levels. This allows analysis of the quality and accuracy of ratings of the particular CRA.

Table 5. The warning signals concerning the potential of conflicts of interest in models ensuring the independence of employees of CRAs in Ukraine

\begin{tabular}{|c|c|c|c|c|c|c|}
\hline \multirow[b]{2}{*}{ No. } & \multirow[b]{2}{*}{ Indicators } & \multicolumn{5}{|c|}{ Credit rating agencies } \\
\hline & & IBI-Rating & Rurik & $\begin{array}{l}\text { Expert- } \\
\text { Rating }\end{array}$ & $\begin{array}{l}\text { Credit- } \\
\text { Rating }\end{array}$ & $\begin{array}{l}\text { Standard- } \\
\text { Rating }\end{array}$ \\
\hline & $\begin{array}{l}\text { No prohibition of the direct or indirect holding } \\
\text { of securities of rated entities }\end{array}$ & $-^{*}$ & $-*$ & $-*$ & $-*$ & $?$ \\
\hline & $\begin{array}{l}\text { No prohibition of the employment position or } \\
\text { directorship at a rated entity }\end{array}$ & $-*$ & $-^{*}$ & $+/-$ & -* & $?$ \\
\hline & $\begin{array}{l}\text { No prohibition of the business relation beyond } \\
\text { ordinary course of business or special purpose } \\
\text { relationship with rated entities }\end{array}$ & $-^{*}$ & $-^{*}$ & $+/-$ & $-*$ & $?$ \\
\hline & $\begin{array}{l}\text { No prohibition of the receipt of gifts from rated } \\
\text { entities }\end{array}$ & $-^{*}$ & $-^{*}$ & + & $-^{*}$ & $?$ \\
\hline & $\begin{array}{l}\text { The determination of analysts' compensations } \\
\text { based on rating fees }\end{array}$ & $-*$ & $-*$ & + & $-*$ & $?$ \\
\hline & $\begin{array}{l}\text { The absence of a rotation mechanism for } \\
\text { analysts and members of credit rating committee }\end{array}$ & + & + & + & + & $?$ \\
\hline \multicolumn{2}{|c|}{$\begin{array}{l}\text { The total number of detected signals about the threat } \\
\text { of conflicts of interest escalation }\end{array}$} & 1 & 1 & 4 & 1 & 6 \\
\hline
\end{tabular}




\subsection{The potential of conflicts of interest at the operational (analyst) level}

As can be seen from Table 5, in corporate codes of conduct the majority of Ukrainian CRAs (except Expert-Rating and Standard-Rating) declare the independence of their employees. At the same time, even using the very limited public data, it is possible to trace the close business ties of top-managers of authorized CRAs with participants of financial services' markets which they had in the past. We believe it could potentially lead to conflicts of interest.

For example, the chief accountant of Rurik previously held the position of chief accountant of Ukrprivinvest, the joint-stock financial investment company, which specializes in "other auxiliary activity in the sphere of financial services, except insurance and pension funding" (that is - activities in keeping the register of owners of registered securities). Also, the chief accountant of IBI Rating had previously held the position of chief accountant of Ostriv, consulting firm, which is working "...on the market of valuation services, securities, financial and legal services and the development of investment strategies, and provides, in particular, ... services of registrar and securities trader" (Ostriv, 2017).
The independence of rating analysts and members of credit rating committees could also be broken by the long-term relationships with the same rated entities. That's why, for example EU Regulation (The European Parliament and the Council, 2009) demands the use of rotation mechanisms which provide a gradual change of the members of analytical teams and credit rating committees. During the research we were unable to find any information about the use by Ukrainian CRAs of such a rotation mechanisms.

\section{THE GENERALIZATION OF THE RESULTS}

The analysis, conducted using proposed system of indicators, allows to conclude that at the beginning of 2017 the most sensitive to the risk of conflicts of interest were "Standard Rating" (74\% of threat signals of the total number of indicators), "Expert Rating" (57\%) and "Rurik” (37\%) (Figure 1).

The highest potential of conflicts' of interest escalation was identified in the models of financial activities $(80 \%$ of threat signals of the total number of indicators of that group) and models of ownership of Ukrainian CRAs (63\%).
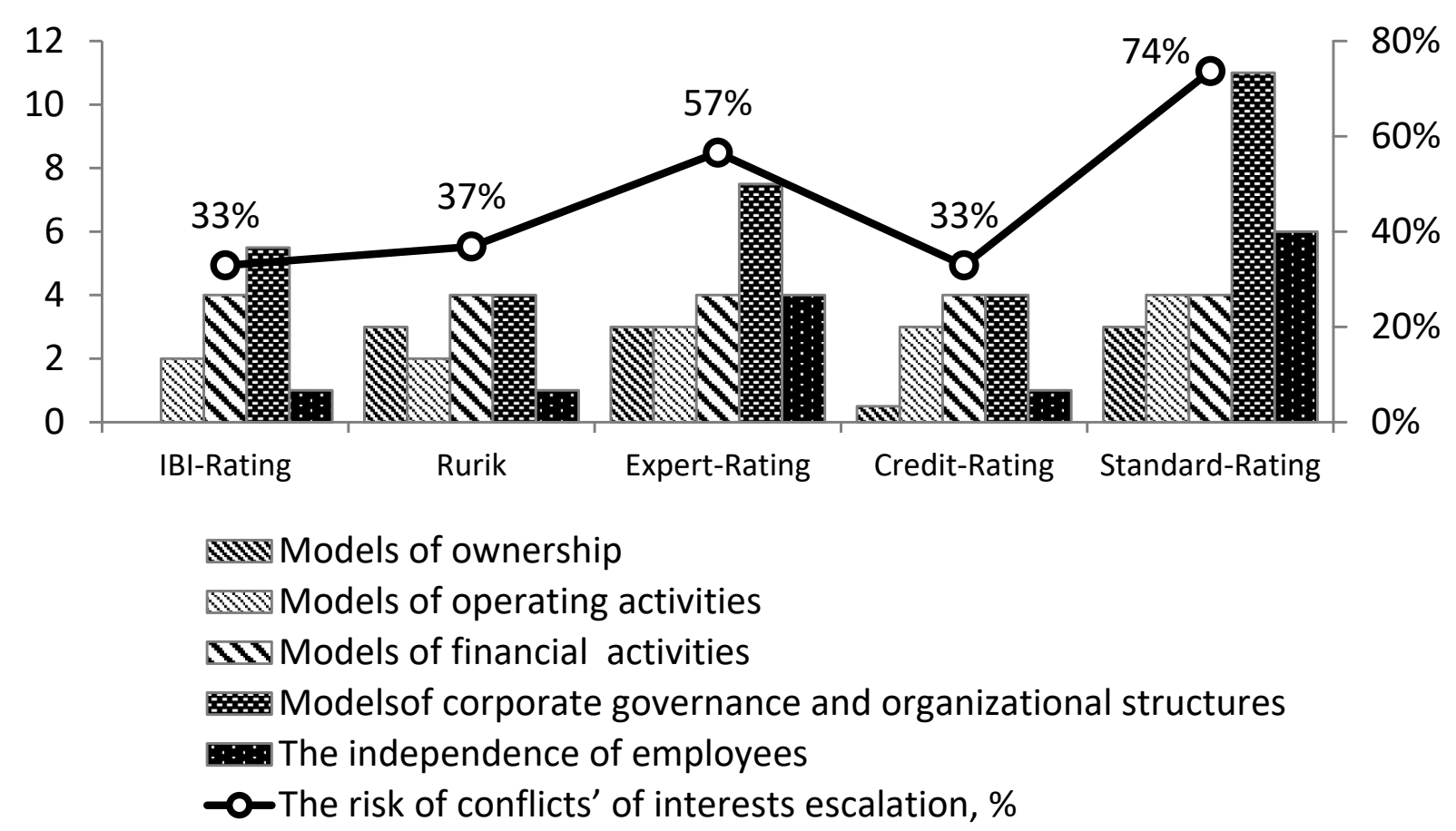

Figure 1. The total number of detected signals about the threat of conflicts' of interest escalation in the activities of Ukrainian CRAs (at the beginning of 2017) 


\section{CONCLUSION}

When interpreting the results of the analysis, it is worth considering the limitations of the research methodology outlined in the beginning of the article. In particular, overestimation and underestimation errors in the results of using the proposed system of indicators could potentially arise due to the fact that the research was of remote nature and based solely on the content analysis of public data, the volume of which in the Ukrainian reality, unfortunately, is significantly limited.

Therefore, it should be emphasized that obtained estimates of the level of risk of conflicts of interest may differ significantly from the actual level of such risk in the activities of authorized CRAs in Ukraine. On the one hand, we tried to follow the principle of conservatism. That's why the lack of the information regarding a particular indicator was considered as a signal of the potential danger of conflicts of interest escalation. On the other hand, we assumed that in practice CRAs strictly hold their own statements and obligations in the management of conflicts of interest declared by them at the official sites as well as in their corporate codes of conduct. However, during the research we have found numerous instances of violation by agencies of such statements and obligations that on the contrary may indicate an underestimation of the actual level of the risk of conflicts' of interest escalation.

In practice the intensity of conflicts of interest also depends largely on the specifics of certain CRA, which in turn depends on the wide spectrum of factors that are difficult to assess remotely through the content analysis of public information. Among those factors are professional skills, experience, integrity of managers, analysts and other employees of the agency, available resources, technology, etc. In addition, even well-designed models of ownership, business and financial activities, corporate governance and organizational structure, mechanisms and procedures of internal control will not generate the desired effect if CRA's corporate culture is not built on the principles of integrity, strict compliance with a corporate code of conduct, laws and regulations.

Therefore, obtained estimations of the risk of conflicts' of interest escalation are worth to be regarded mainly as signals of the potentially high sensitivity of CRA to that risk.

Such signals can be especially used by the regulators for carrying out remote monitoring activities of CRAs for adopting supervisory and regulatory decisions. In turn, managers and owners of rating agencies can conduct a more detailed analysis of the detected potential sources of conflict of interest with the aim of identification, localization and elimination of shortcomings in the system of conflict of interest management at the corporate and operational levels.

The results of the research also indicate that it is significantly advisable for Ukrainian CRAs to pay more attention to ensuring of their activities' transparency. We were unable to obtain any information for many indicators. In addition, the information on more than half of the indicators was found in such depths of annual reports and corporate codes of conduct which are unlikely to be got even by the most inquisitive researchers.

But it also should be highlighted that the concept of sensitivity to the risk of conflicts of interest and the concept of transparency of CRAs' activities should be clearly distinguished. Practically the agency with informative online resources can also demonstrate significant problems with the management of conflicts of interest, violating its own statements and commitments, declared on the official website as well as in corporate code of conduct. 


\section{REFERENCES}

1. Babenko, M., \& Chernyj, R. (2012). Tesnyj krug. Kommersant-Ukraina. Retrieved from http://www.credit-rating.ua/ru/ events/200/13259/

2. Bai, L. (2010). On Regulating Conflict of Interests in the Credit Rating Industry. Retrieved from http://ssrn.com/abstract $=1594462$

3. Beinert C., Reichling, P., \& Vogt, B. (2007). The Discriminative Power of Rating Functions. Banks and Bank Systems, 2(1). Retrieved from https://businessperspectives.org/journals/banksand-bank-systems/issue-152/ the-discriminative-power-ofrating-functions

4. Bergevin, P. (2010). Addicted to Ratings: The Case for Reducing Governments' Reliance on Credit Ratings. C.D. Howe Institute Backgrounder, 130. Retrieved from https://ideas.repec.org/a/ cdh/backgr/130.html (accessed on 1 June 2016).

5. BizDb.co.uk. (2017). Global Private Rating Company Standardrating Ltd: General Information. Retrieved from http://www.bizdb.co.uk/company/global-private-ratingcompany-standardrating-ltd07386300/\#director_id355091

6. Coffee, John C., Jr. (2011). Ratings Reform: The Good, The Bad, and The Ugly. Harvard Business Law Review, 1. Retrieved from http://www.hblr.org/ wp-content/uploads/2014/09/ Ratings-Reform.pdf

7. Crumley, D. G. (2012). Credit Rating Agencies and Conflicts of interest. Retrieved from https://repositories.lib.utexas. edu/bitstream/handle/2152/ ETD-UT-2012-05-5115/ CRUMLEY-MASTERS-REPORT. pdf? sequence $=1$

8. Endole.co.uk. (2017). Mr. Jason Hughes Director Profile. Retrieved from http://www. endole.co.uk/profile/profile_new. php?id=09651116
9. Fulghieri, P., Strobl G., \& Xia, H. (2011). The Economics of Solicited and Unsolicited Credit Ratings. Retrieved from http:// faculty.haas.berkeley.edu/mopp/ conference/strobl.pdf

10. Katz, J., Salinas, E., \& Stephanou, C. (2009). Credit Rating Agencies. No Easy Solutions. Retrieved from http://rru.worldbank.org/ documents/CrisisResponse/ Note8.pdf

11. Kozmenko, S., \& Plastun, O. (2012). The necessity of stock markets information incorporation into the methodology of credit rating agencies. Investment Management and Financial Innovations, 9(3). Retrieved from https://businessperspectives.org/ journals/investment-management-and-financial-innovations/ issue-88/the-necessity-of-stockmarkets-information-incorporation-into-the-methodology-ofcredit-rating-agencies

12. NSSMC. (2012). Pro zatverdzhennia Poriadku podannia informatsii upovnovazhenymy reitynhovymy ahentstvamy. Rishennia NKTsPFR vid 11.12.2012 No. 1767. Retrieved from http://zakon4.rada.gov. ua/laws/show/z0025-13/ print 1447000662321818

13. NSSMC. (2015). Pro konkurs $z$ vyznachennia upovnovazhenykh reitynhovykh ahentstv. Polozhennia, zatverdzhene Rishenniam NKTsPFR vid 23.03.2015 No. 364. Retrieved from http://zakon3.rada.gov.ua/ laws/show/z0416-15

14. Opp, C. C., Opp, M. M., \& Harris, M. (2013). Rating agencies in the face of regulation. Journal of Financial Economics, 108, 46-61. Retrieved from http://faculty.haas.berkeley.edu/ mopp/Research/fame.pdf

15. Ostriv. (2017). Pro kompaniiu. Sait ZAT "Konsaltynhova Firma "Ostriv". Retrieved from http:// konsaltingova-firma-ostriv. business-guide.com.ua/
16. Partnoy, F. (2009). Rethinking Regulation of Credit Rating Agencies: An Institutional Investor Perspective. San Diego Legal Studies Paper, 09014. Retrieved from http:// papers.ssrn.com/sol3/papers. cfm?abstract_id $=1430608$

17. Pererva, H. (2012). Tochnist otsinok reitynhovykh ahentstv. Nezalezhnyi Audytor, 10. Retrieved from http://n-auditor. com.ua/uk/component/na archive $/ 606$ ? view $=$ material (in Ukrainain)

18. Pro dotrymannia etychnykh norm i standartiv povedinky na rynku reitynhovykh posluh Ukrainy: Memorandum, pidpysanyi RA IBI-Reitynh, NRA Riurik y RA EkspertReitynh 24.11.2010. Retrieved from http://www.expert-rating. com/data/upload/Konferencii/ MEMORANDUM.pdf

19. Prozorro.gov.ua (2016).

Nadannia posluh $z$ reitynhuvannia: oholoshennia pro provedennia doporohovoi zakupivli Upravlinnia stratehichnoho rozvytku mista Ternopilskoi miskoi rady. Retrieved from https://prozorro gov.ua/tender/UA-2016-04-25000098-a

20. Reitynhovi ahentstva. (2017). Zahalnodostupna informatsiina baza danykh NKTsPFR. Retrieved from http://stockmarket.gov.ua/db/agency/nreg/

21. The Board of the IOSCO. (2012). Credit Rating Agencies: Internal Controls Designed to Ensure the Integrity of the Credit Rating Process and Procedures to Manage Conflicts of interest. Retrieved from http://www. iosco.org/library/pubdocs/pdf/ IOSCOPD398.pdf

22. The Board of the IOSCO. (2015). Code of Conduct Fundamentals For Credit Rating Agencies. Retrieved from http://www. iosco.org/library/pubdocs/pdf/ IOSCOPD482.pdf 
23. The European Parliament and the Council. (2009, September). Regulation (EC) No. 1060/2009 On credit rating agencies. Retrieved from http://eur-lex.europa.eu/ legal-content/EN/TXT/?uri$=$ CELEX\%3A32009R1060

24. The European Parliament and the Council. (2012, March 21) Regulation (EC) No. 449/2012 Supplementing Regulation (EC) No 1060/2009 of the
European Parliament and of the Council with regard to regulatory technical standards on information for registration and certification of credit rating agencies. Retrieved from http:// eur-lex.europa.eu/legal-content/ $\mathrm{EN} / \mathrm{TXT} / \mathrm{PDF}$ /?uri=CELEX:3201 2R0449\&from=en

25. The European Securities and Markets Authority. (2011, December 22). Regulatory technical standards on the information for registration and certification of credit rating agencies. Retrieved from https://www.esma. europa.eu/sites/default/files/library/2015/11/2011_463.pdf

26. The Technical Committee of the IOSCO. (2003). Report on the Activities of Credit Rating Agencies. Retrieved from https:// www.iosco.org/library/pubdocs/ pdf/IOSCOPD153.pdf 